Discussion Paper No. 04-59

\title{
A Simulation Method to Measure the Tax Burden on Highly Skilled Manpower
}

Christina Elschner and Robert Schwager

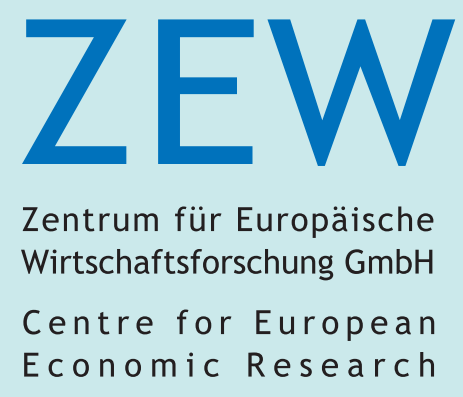


Discussion Paper No. 04-59

\title{
A Simulation Method to Measure the Tax Burden on Highly Skilled Manpower
}

\author{
Christina Elschner and Robert Schwager
}

Download this ZEW Discussion Paper from our ftp server:

\author{
ftp://ftp.zew.de/pub/zew-docs/dp/dp0459.pdf
}

Die Discussion Papers dienen einer möglichst schnellen Verbreitung von neueren Forschungsarbeiten des ZEW. Die Beiträge liegen in alleiniger Verantwortung der Autoren und stellen nicht notwendigerweise die Meinung des ZEW dar.

Discussion Papers are intended to make results of ZEW research promptly available to other economists in order to encourage discussion and suggestions for revisions. The authors are solely responsible for the contents which do not necessarily represent the opinion of the ZEW. 


\section{Non-Technical Summary}

International comparisons of business locations emphasise the importance of taxation. This kind of research is focussed upon the tax burden on capital investment. However, since qualified workers become increasingly mobile internationally, companies should also pay attention to the tax burden imposed on the production factor labour at the firm's location - an issue so far largely neglected by research. The present paper aims at filling this gap by analysing the tax burden on highly skilled labour from the perspective of the company. We take into account all direct taxes and social security contributions inasmuch as they qualify as taxes from an economic point of view. Our approach allows for old-age provision as part of the compensation package, taking account of the resulting benefits and tax liabilities in an explicit inter-temporal model. We apply the model to the tax and social security systems of France, Germany, the UK, and the USA, and discuss the results.

We measure the employer's expenses for a highly qualified employee under the assumption that the highly qualified has to obtain an internationally comparable disposable income after taxes. We consider income taxes including surcharges, tax-like social security contributions as well as payroll taxes paid by the company. The employee's income is assessed for tax and social security purposes in several periods during the life cycle. Using this method, we derive effective average tax rates for several income levels, structures of compensation, and family situations which are typical for highly qualified employees.

The results show that there are considerable differences in tax burden across the countries studied. The USA and the UK most of the time have lower tax burdens than Germany and France. Considering families, Germany moves up to the second rank for low incomes. The effective average tax rate increases with increasing income despite income ceilings for social security, as all tax systems considered have progressive tax schedules.

The main tax drivers for the tax burden on highly skilled labour are the tax rate of the personal income tax and income ceilings and contribution rates to social security. Especially with lower incomes the employee's family situation is important for the tax burden. The composition of the compensation package has a minor influence on the tax burden if one compares old-age provision with a hypothetical investment yielding tax free interest. If such interest income is taxed at the top marginal rate of the personal income tax, however, the effective average tax rate can be reduced substantially by increasing the share of occupational pension plans in the compensation package. 


\title{
A Simulation Method to Measure the Tax Burden on Highly Skilled Manpower ${ }^{1}$
}

\author{
Christina Elschner \\ Zentrum für Europäische Wirtschaftsforschung, ${ }^{2}$ Mannheim, and \\ Universität Mannheim \\ Robert Schwager \\ Georg-August-Universität Göttingen ${ }^{3}$ and \\ Zentrum für Europäische Wirtschaftsforschung, Mannheim
}

July 2004

JEL: H24, H21, H55

Keywords: personal income tax, highly skilled employees, effective tax burden, pensions

\begin{abstract}
A model is presented for simulating the tax burden on highly skilled manpower. The effective average tax rate, defined as the relative wedge between total remuneration and disposable income, is computed. Income and payroll taxes and social security contributions not yielding an equivalent benefit are taken into account. The compensation package consists of cash payments and old-age provision. To integrate retirement benefits and their tax treatment, an inter-temporal approach is used. The results indicate that Germany and France have higher tax burdens than the UK and the USA, that Germany grants the strongest tax relief for families, and that occupational pension plans are favourable in all countries.
\end{abstract}

\footnotetext{
${ }^{1}$ We are indebted to the $<<$ IBC BAK International Benchmark Club $>>\circledR$ by BAK Basel Economics for financing this research. We also thank the steering committee of the IBC taxation module as well as the module's panel of experts in personnel management for advice and encouragement. Special thanks go to Otto H. Jacobs, Lothar Lammersen, and Christoph Spengel for encouragement and very helpful discussions. All remaining errors are our own.

${ }^{2}$ L7,1, D-68161 Mannheim, phone: +49/621/1235162, fax: +49/621/1235223, email: elschner@zew.de

${ }^{3}$ Volkswirtschaftliches Seminar, Platz der Göttinger Sieben 3, D-37073 Göttingen, phone:

+49/551/397293, email: rschwag@uni-goettingen.de
} 


\section{Introduction}

International comparisons of business locations emphasise the importance of taxation. For example, the European Commission has funded several comparative studies on the effective tax burden of companies in the European Union (see European Commission 1992, 2002). This kind of research is focussed upon the tax burden on capital investment. However, since qualified workers become increasingly mobile internationally, companies should also pay attention to the tax burden imposed on the production factor labour at the firm's location - an issue so far largely neglected by research. The present paper aims at filling this gap by analysing the tax burden on highly skilled labour. In line with received measures of capital taxation, we use the effective average tax rate as a measure for the relative additional amount that has to be paid by the company if it wants to remunerate a highly qualified employee with a predetermined disposable income.

Our approach is characterised by four distinctive features. Firstly, we treat the tax burden on highly skilled employees from the perspective of the company. Secondly, we take into account all direct taxes and social security contributions inasmuch as they qualify as taxes from an economic point of view. Thirdly, our approach allows for oldage provision as part of the compensation package, taking account of the resulting benefits and tax liabilities in an explicit inter-temporal model. Fourthly, the final purpose of our research being international comparisons, we apply the model to the tax and social security systems of four countries and discuss the results.

\section{Tax burden on qualified labour as an issue for the firm.}

To see why the tax burden on labour should be a concern for companies, observe that highly qualified specialists or managerial staff are typically mobile across jurisdictional boundaries. ${ }^{1}$ Such an employee will evaluate different employment opportunities on the basis of the disposable income he receives after taxes. Our international comparison is thus based on the assumption that the employee obtains a fixed disposable income which he can earn at all locations. This however implies that the tax to be paid on an employee's income is shifted onto the company. Thus, taxes and social security contributions payable by the employee increase labour costs as perceived by the firm. Adding labour related charges paid by the employer results in the total remuneration which the company has to spend so as to be able to hire the employee. Dividing the difference between total remuneration and disposable income, the tax wedge, by the total remuneration, one obtains the effective average tax rate (EATR) which is the measure for the tax burden on highly skilled manpower we propose.

The higher the EATR, the more the employer has to spend in order to compensate an internationally mobile employee. Or, to express it from the perspective of regional

\footnotetext{
${ }^{1}$ According to Winkelmann et al. (2001: 33), 38.9 per cent of all companies in Germany employ university graduates originating from foreign countries. In the UK, the corresponding share is even 49.6 per cent. The industries most inclined to employ internationally mobile highly skilled staff are research and development, information technology, and chemicals (Winkelmann et al. 2001: 34). See also Winkelmann (2002).
} 
politics, the higher the EATR, the less attractive is a country for companies employing highly qualified employees. When assessing the attractiveness of regions for highly skilled labour in this way, it should be stressed that we do not intend to provide a comprehensive theory of migration. More modestly, our methodology aims at isolating the tax burden as one important factor for the attractiveness of locations. Thus, we do not question the importance of other factors influencing a job decision, such as job satisfaction, cost of living, local schools, or environmental amenities. However, in order to clearly display international differences in taxation, we purposefully abstract from these factors.

Taxes and tax-like social security contributions.

The tax wedge is composed of all direct taxes and charges paid by employer or employee in connection with the total remuneration. This obviously includes income taxes and surcharges, as well as payroll taxes levied on aggregate salaries or wages. Concerning contributions to the various branches of social security, our leading principle is to consider such payments as tax-like charges if they do not yield a specific benefit to the individual employee. We assume that such a benefit is provided by contributions to public health care systems, whereas contributions to insurances against unemployment and employment-related injuries qualify as taxes.

Since mandatory public pension schemes differ widely among countries regarding both contributions and benefits it would neither be satisfactory simply to add these contributions to the tax burden nor simply to ignore them. Instead, we carefully account for the benefits provided by such schemes according to the regulations currently in force in each country. By using this approach, we take account of the fact that payments into a public pension scheme can at least partially be considered as insurance premium even if the benefit provided is typically not actuarially fair.

We do not include indirect taxes in our measure of the tax burden on labour. At first glance, this may not seem satisfactory since in general equilibrium, the value added tax is equivalent to a tax on wages, pure profits, and existing wealth (see for example Gravelle (1991), Metcalf (1996), and Gaube and Schwager (2003)). The present model, however, is a partial equilibrium approach aiming at isolating the taxes triggered directly by the employment decision. Since higher indirect taxes primarily show up in higher prices, leaving consumption taxes out of the simulation is in line with disregarding the cost of living and other location factors.

\section{Compensation package and inter-temporal approach.}

Our aim is to quantify the tax burden on the income generated by working during one period. However, the compensation of highly qualified employees typically does not only consist of income which is paid out in the remuneration period. In particular, contributions to old-age provision - both publicly mandated and voluntary - provide benefits only after retirement. This form of compensation triggers tax liabilities in different periods. For this reason, a satisfactory assessment of the effective tax burden on employees earning mixed compensation packages has to account for the inter-temporal structure of income, tax and social security payments. Thus we adapt our concept to account for disposable incomes generated in the remuneration period but accruing in different periods. In such an inter-temporal setting the EATR is defined as the difference between total remuneration and the sum of appropriately discounted disposable 
incomes generated by working in the remuneration period. To sum up, the effective average tax rate EATR supplies information about current and future tax payments and charges that occur in context with the total remuneration earned in one period.

\section{International comparison.}

In the present paper, the model is applied to France, Germany, the UK, and the USA. In this comparison we vary the level of disposable income from $€ 40,000$ to $€ 200,000$. Moreover, we consider both a single person and a family of four. The results indicate that throughout all income levels, effective tax burdens in France and Germany exceed those of the UK and the USA. On the other hand, Germany grants the highest tax relief for families among these four countries, whereas in the UK there is almost no such relief at the top end of the income scale. These applications mainly serve as an illustration of the working of the model since the focus of the present paper is on the method and not on results. Readers interested primarily in results are referred to the companion study Elschner and Schwager (2004a) which covers a much wider geographical area and provides many more variations of the model details.

\section{Outline of the paper.}

The remainder of the paper is organised as follows. In the next section we take up the defining characteristics of our approach and relate them to other concepts of effective tax burdens, both on capital and on labour. Section 3 describes the formal model. In section 4 we present the results of the international comparison. Finally, section 5 puts the results in perspective and discusses some future lines of research. An appendix contains summary tables of the tax and social security regulations used as well as some more detailed results.

\section{Other Concepts of Effective Tax Rates}

\section{Measures of company tax burdens.}

The basic structure of our concept of an EATR is borrowed from acknowledged methods of measuring the tax burden of companies such as the effective marginal tax rate introduced by King and Fullerton (1984), the effective average tax rate proposed by Devereux and Griffith $(1999,2003)$, or the effective tax burden computed with the European Tax Analyzer simulation model (see Jacobs and Spengel, 1996). In all these concepts, a wedge between a pre-tax value and an after tax value is divided by the pretax value so as to obtain an effective rate of taxation. The concepts by King and Fullerton and Devereux and Griffith only assess the tax burden on an additional unit of investment. Contrary to that, we assess the tax on the total income of the individual rather than the tax on a marginal increase of his working time. In that respect our concept is closer to the European Tax Analyzer model which quantifies the tax burden of an entire company. In another respect, i.e., regarding the treatment of the employee's disposable income as exogenous, our approach has its counterpart in the measure of effective marginal tax rates by King and Fullerton. When calculating effective marginal tax burdens on investment, one can either fix the post tax return to the investor (the so called fixed-r-case) or the cost of capital which the investment earns (the socalled fixed- $p$-case). Since we fix the post tax income, our approach corresponds to the fixed-r-case, whereas a computation of disposable incomes for exogenous total remuneration resembles rather the fixed- $p$-case. 
Measures of labour tax burdens.

The tax burden on labour has been quantified by several alternative approaches. In analogy to backward looking measures on the taxation of capital income, Mendoza et al. (1994) present effective average tax rates on labour income. These measures are computed by dividing aggregate taxes on labour income by a macroeconomic measure of such income. The advantage of these measures is that they are based on observed data, using actual tax payments. However, this also implies that they cannot provide any information about the effect of specific tax rules on the tax burden. Moreover, by its macroeconomic nature, one cannot determine the tax burden for different economic situations such as income levels or marital status. Backward looking measures are therefore not a suitable guide for the impact of taxation on economic decisions. Their main application lies in providing a quick reference figure for the way taxation interferes with the distribution of incomes among the factors of production on a macroeconomic level.

The EUROMOD research consortium takes a microeconomic approach (see Sutherland, 2001). In this model, the tax and social security contributions as well as welfare entitlements are simulated for a representative sample of the population. While this simulation is similar to the casuistic tax assessment performed in our model, pension entitlements are taken from the data instead of being simulated using the legal regulations, thus introducing a backward looking element in EUROMOD (see Sutherland, 2001: 5). The results of the individual tax assessments are then aggregated into society wide indicators, for example a Gini coefficient, so as to answer a variety of policy questions. Thus, the focus of microsimulation models is not to provide effective tax rates for specific categories of employees but on a microfoundation of aggregate policy analysis. Here, distributional issues are evidently at the centre of interest.

In its publication series on "taxing wages" described by Heady (2003), the OECD takes an approach which is similar to ours in several respects (see OECD, 2002). Also there, the taxes and social security contributions of several types of workers are assessed in a casuistic simulation. An effective average tax rate is then calculated by dividing the resulting tax wedge by total labour costs. As in our approach, income and payroll taxes are considered. However, there are two major differences between our model and the OECD approach. Firstly, unlike the OECD we do not treat social security contributions as a whole as taxes. Instead, we take care to relate as precisely as possible individual benefits procured by contributions to public pension schemes to the payment of these contributions. Secondly, both approaches consider different types of employees. While the OECD concentrates on the average production worker and workers earning 67 or 167 per cent of this worker, our study is explicitly focussed on highly qualified employees. Beyond a mere change in the income level this has two structural consequences which make our model substantially richer than the OECD approach. Firstly, we take care to analyse the specific tax treatment of various compensation components. Secondly, since old-age provision is prominent in the compensation package of highly qualified employees this necessitates an inter-temporal approach.

Several recent studies quantify the intensity of redistribution induced by public pension systems using a simulation approach that is related to ours. For example, Börsch- 
Supan and Reil-Held (2001) estimate the share of transfers, as opposed to insurance benefits, included in payments from the German pay-as-you-go pension system. Using data from the Socio-Economic Panel, a sample of German households, they simulate the pension entitlements of each household by applying the legal pension formula to an estimated earnings history. Fenge and Werding (2003) quantify the tax rates which are implicit in the pay-as-you-go pension systems of selected OECD countries. Similarly to the method proposed in the present paper, this work is also based on an intertemporal simulation model describing the earnings and pension entitlements of a representative individual. Since these studies exclusively focus on pensions they are able to include more details, in particular concerning life-expectancy and demographics. On the other hand, our approach is much broader in scope since we incorporate all taxes and social security contributions which are related to employing the highly qualified person.

To sum up, our model differs from all existing methods by addressing the issue of the tax burden on manpower from the point of view of the company, and by its careful modelling of the tax burden induced at different times by different kinds of compensation.

\section{The Model}

In the present section the method is described in detail. We first define the concept of the effective average tax rate and explain the basic model structure. This consists of the inter-temporal setting, the characteristics of the highly skilled, and definitions of taxes and charges. After that, the relationship between total remuneration, taxes, and disposable income is described formally.

The effective average tax rate.

The two key economic variables in the model are the total remuneration $E^{*}$ and the disposable income $E$. Total remuneration is the amount the company has to pay in order to obtain the labour supply by the highly skilled employee for one year. Disposable income is the amount the employee obtains in exchange for this labour supply. The difference $E^{*}-E$, called the tax wedge, is taken by government. Dividing the tax wedge by total remuneration we obtain the effective average tax rate

$$
E A T R=\frac{E^{*}-E}{E^{*}}
$$

This is the measure of effective tax burden proposed in this paper.

Inter-temporal structure.

The EATR is to be understood as the tax burden imposed on the earnings of one year. However, some parts of the employee's earnings are only available to him in later periods. Specifically, pension schemes procure a benefit only after retirement although the contributions clearly are part of the compensation received for working. For that reason, we consider an explicit inter-temporal structure with the employee's working life covering periods $t=0,1, \ldots t_{0}, \ldots, t_{p}-1$, and the retirement phase extending over periods, $t=t_{p}, t_{p}+1, \ldots, t_{p}+P-1$. Two periods are of specific interest: By working dur- 
ing the year $t_{0}$ the employee earns the remuneration the tax burden of which is to be evaluated. This period is called the remuneration period, and the disposable income received by the employee in this period is denoted by $E_{0}$. The second period of interest is the first period of the retirement phase, $t_{p}$. As explained in detail at the end of this section we transform the benefit procured by pension schemes into an annuity during the entire retirement phase. Thus, the remuneration earned by working in $t_{0}$ generates a constant flow of disposable incomes $E_{p}$ in $t_{p}$ and each of the subsequent $P-1$ years of retirement. To evaluate this flow, a constant interest rate $\bar{r}$ is assumed, with the discount factor denoted by $\bar{\delta}=1 /(1+\bar{r})$. The interest rate $\bar{r}$ is the individual rate of return the employee obtains for his savings, possibly net of income taxes levied on interest income.

The disposable income $E$ is then obtained by computing the present value of this flow at time $t_{0}$ plus the disposable income $E_{0}$ in the remuneration period:

$$
E=E_{0}+\sum_{t=t_{p}}^{t_{p}+P-1} \frac{E_{p}}{(1+\bar{r})^{t-t_{0}}}=E_{0}+\bar{\delta}^{t_{p}-t_{0}} \cdot\left(\frac{1-\bar{\delta}^{P}}{1-\bar{\delta}}\right) \cdot E_{p}
$$

Our analysis aims at deriving the total remuneration necessary to provide the skilled employee with a given disposable income which he could earn at another location. Thus, our simulation has to find a value of $E^{*}$ which, given the tax and social security regulations in force in the country under consideration, leads to the exogenously fixed $E$ according to equation (2). In practice, however, taxes and social security contributions are imposed according to quantities which are related to total remuneration rather than disposable income. For that reason, $E^{*}$ is computed by an iterative procedure. Starting from an arbitrary value of total remuneration tax and social security liabilities are assessed yielding some disposable income. If this value exceeds (falls short of) the disposable income assumed to be required by the employee, the assessment is repeated for a lower (higher) total remuneration. This loop is carried out until the required disposable income is achieved.

\section{Taxes and social security charges.}

The core of the simulation model is thus the determination of disposable income $E_{0}$ and $E_{p}$ from tax and social security regulations when total remuneration $E^{*}$ is given. The computation of EATR takes into account income taxes and surcharges, payroll taxes paid by the company, and those contributions to social security systems which do not yield an equivalent individual benefit to the employee. ${ }^{2} \mathrm{We}$ assume this to be the case for unemployment insurance premiums, since competition for the mobile employee rules out unemployment, and for accident insurance, since we do not think of high risk manual work. Contrary to that, we abstract from redistributive elements in health care systems and do not consider those premiums to be tax-like. Inasmuch as contributions to the first pillar of old-age insurance have to be seen as a tax-like charge, this charge appears in the form of a lower pension compared to a pension possible under market conditions.

\footnotetext{
${ }^{2}$ See tables A-1 to A-4 in the appendix for a description of the tax and social security regulations taken into account in the simulations.
} 
Tax and social security legislation usually does not refer to the economic concepts of total remuneration and disposable income. Instead, the assessment base is a legally defined quantity called taxable or gross income. Since the bases of taxes and social security contributions differ in most cases we denote taxable income by $e^{t}$ and gross income for social security purposes by $e^{g}$. The tax schedule $T\left(e^{t}, x\right)$ determines the income tax due after deduction of any tax credit. In addition to taxable income, it may depend on a vector of personal characteristics, denoted by $x$, such as family status.

Regarding social security we distinguish between contributions to the first pillar of old-age insurance according to the schedule $\Omega\left(e^{g}\right)$ and other contributions according to the schedule $\Gamma\left(e^{g}\right)$. We denote by $\Gamma_{\tau}\left(e^{g}\right)$ those contributions, contained in $\Gamma\left(e^{g}\right)$, which in our evaluation are considered as tax-like without an equivalent benefit. Usually, both employer and employee pay contributions to the systems of social security. We designate contributions applying to the employer with a hat $\left(^{\wedge}\right)$ and those applying to the employee with a bar $\left(^{-}\right)$. Thus we have $\Omega\left(e^{g}\right)=\bar{\Omega}\left(e^{g}\right)+\hat{\Omega}\left(e^{g}\right)$ and $\Gamma\left(e^{g}\right)=\bar{\Gamma}\left(e^{g}\right)+\hat{\Gamma}\left(e^{g}\right)$ for all $e^{g}$. Finally, payroll taxes depend on gross income, and are denoted by $\Theta\left(e^{g}\right)$. The social security schedules in practice typically are piecewise linear functions where several marginal rates are applied to the various income brackets. In particular, there may exist income ceilings such that the amount of contributions to be paid remains constant as soon as gross income reaches the ceiling. All schedules, including payroll taxes, however, are continuous and have first derivatives of at least zero and below one. Moreover, contributions are zero if gross income is zero and the average social security payment $\left[\Omega\left(e^{g}\right)+\Gamma\left(e^{g}\right)\right] / e^{g}$ is bounded away from one.

The typical highly skilled employee.

The model employee in our analysis represents a typical highly qualified employee. $\mathrm{He}$ is defined by three main characteristics: the income level, the composition of compensation components, and as a personal characteristics the marital status and the number of children. Since we deal with skilled employees, the income level is rather high, varying between disposable incomes of $€ 40,000$ and $€ 200,000$. Concerning the family situation, we consider both a single employee and a family of four where the highly skilled employee is the only earner.

The compensation package considered consists of cash compensation and old-age provision. The shares of these two compensation components in total remuneration are fixed $^{3}$ and denoted by $f_{c}$ for cash and $f_{p}$ for old-age provision, with $f_{c}+f_{p}=1$. The compensation component old-age provision is itself composed of two parts. Firstly, there are contributions to occupational pension plans, denoted by $C$. These are paid by both employee and employer, with the shares of $C$ contributed by the employee and the employer being $\beta$ and $(1-\beta)$ respectively. Secondly, compulsory contributions to the first pillar of public old-age insurance $\Omega\left(e^{g}\right)$ naturally are part of old-age provision yielding

\footnotetext{
${ }^{3}$ For the numerical values used for $f_{c}$ and $f_{p}$ as well as other parameters in the simulations, see table A-5 in the appendix.
} 


$$
f_{p} E^{*}=C+\Omega\left(e^{g}\right) .
$$

Notice that the percentage $f_{p}$ of total remuneration spent for old-age contributions is fixed by assumption. Also, the country-specific amount of contributions to the first pillar of the old-age insurance is fixed by law. As a consequence the free variable in equation (3) is the amount of contributions to the occupational pension scheme. These contributions therefore depend on $f_{p}$ and on the country-specific public pension scheme.

Since the shares $f_{c}$ and $f_{p}$ of both compensation components refer to total remuneration, social security contributions and payroll taxes have to be assigned to one of the two compensation components. While contributions to the first pillar of old-age insurance are part of old-age provision according to (3) we assume that all other contributions count towards the compensation component cash. Denoting by $I$ the cash payment that actually flows to the employee after deduction of social security contributions, cash compensation is then equal to

$$
f_{c} E^{*}=I+\Gamma\left(e^{g}\right)+\Theta\left(e^{g}\right) .
$$

Gross income in the remuneration period.

In the remainder of this section, we describe how disposable income is derived given the assumptions on the compensation package and social security charges. We begin with the remuneration period. For that period, it has to be explained how the unknown variables $e^{g}$ and $e^{t}$ are derived from total remuneration $E^{*}$.

The employer's contributions to social insurance $\hat{\Omega}\left(e^{g}\right)$ and $\hat{\Gamma}\left(e^{g}\right)$ as well as payroll taxes $\Theta\left(e^{g}\right)$ usually are not part of gross income. However, in some countries contributions to occupational pension plans are part of gross income and thus liable to social insurance. Denoting therefore by $\hat{z}(\bar{z})$ the fraction of the employer's (employee's) contributions to occupational pension plans which are part of gross income according to social security regulations the latter can be obtained as

$$
e^{g}=E^{*}-[(1-\hat{z})(1-\beta)+(1-\bar{z}) \beta] C-\hat{\Gamma}\left(e^{g}\right)-\hat{\Omega}\left(e^{g}\right)-\Theta\left(e^{g}\right) .
$$

Alternatively, gross income can also be obtained by adding to the cash income $I$ the employee's contributions to social insurance, as well as the part of employer's and employee's contributions to occupational pension plans which are subject to social security:

$$
e^{g}=I+[\bar{z} \beta+\hat{z}(1-\beta)] C+\bar{\Gamma}\left(e^{g}\right)+\bar{\Omega}\left(e^{g}\right) .
$$

Solving equation (3) for $C$, inserting in (5), and rearranging yields ${ }^{4}$

$$
e^{g}-\bar{\Omega}\left(e^{g}\right)=E^{*}\left[f_{c}+[\beta \bar{z}+(1-\beta) \hat{z}] f_{p}\right]-\hat{\Gamma}\left(e^{g}\right)-\Theta\left(e^{g}\right)-\Omega\left(e^{g}\right)[\beta \bar{z}+(1-\beta) \hat{z}] .
$$

\footnotetext{
${ }^{4}$ The same result can be obtained by using (6) instead of (5) when $I$ is eliminated with the help of (4).
} 
From $\bar{\Omega}^{\prime}\left(e^{g}\right)<1$ and $\hat{\Omega}^{\prime}\left(e^{g}\right), \hat{\Gamma}^{\prime}\left(e^{g}\right), \Theta^{\prime}\left(e^{g}\right) \geq 0$, in this equation, the left hand side is strictly increasing and the right hand side is weakly decreasing in $e^{g}$. Moreover, when $e^{g}=0$ the left-hand-side is zero while the right-hand side is positive. Finally, as gross income grows without bound, the left hand side approaches infinity since average contributions are bounded below one. Thus there exists a unique solution $e^{g}$ to (7). This solution is the gross income for social security purposes which corresponds to total remuneration $E^{*}$.

As an illustration, consider linear schedules for all social security contributions, no payroll taxes, and assume that the employer's (employee's) contributions to occupational pension plans are not (are fully) part of gross income, that is $\bar{\Omega}\left(e^{g}\right)=\bar{\omega} e^{g}$, $\hat{\Omega}\left(e^{g}\right)=\hat{\omega} e^{g}, \bar{\Gamma}\left(e^{g}\right)=\bar{\gamma} e^{g}, \hat{\Gamma}\left(e^{g}\right)=\hat{\gamma} e^{g}, \Theta\left(e^{g}\right)=0$, and $\hat{z}=0, \bar{z}=1$. Then (7) can be solved explicitly for gross income yielding

$$
e^{g}=\frac{E^{*}\left(f_{c}+\beta f_{p}\right)}{1+\hat{\gamma}-\bar{\omega}+\beta \omega}
$$

The taxable income $e^{t}$ is the difference between the gross income $e^{g}$ and the deductions $d_{0}$ available to a taxpayer who receives work income. For example, such deductions may be granted for business-related expenses, contributions to social security including the pension system, children, and personal allowances. Thus,

$$
e^{t}=e^{g}-d_{0} .
$$

On this taxable income, the tax schedule is applied, where personal characteristics take the values $x_{0}$ applying in period $t_{0}$, yielding the tax payment $T\left(e^{t}, x_{0}\right)$.

\section{The disposable income in the remuneration period}

As the cash component is the only income that initiates direct payments to the employee, the disposable income of period $t_{0}$ is the difference of cash compensation less taxes and tax-like social security charges other than for compulsory public pensions:

$$
E_{0}=f_{c} E^{*}-T\left(e^{t}, x_{0}\right)-\Theta\left(e^{g}\right)-\Gamma_{\tau}\left(e^{g}\right) .
$$

\section{The pension period.}

Following our inter-temporal setting, the benefits procured by old-age provision only accrue in the retirement phase. In order to derive the annual disposable income $E_{p}$ during this phase, one has to quantify not only the resulting pension annuities but also the tax levied upon pension income during retirement. Moreover, pension payments received are the result of contributions during the entire working phase and hence are not directly attributable to contributions paid in period $t_{0}$. Therefore, the pensions procured by working in the remuneration period have to be isolated from other old-age income and then be subject to tax so as to arrive at $E_{p}$.

A simple way to determine the period-specific disposable income $E_{p}$ would be to calculate the pension payments that result from old-age contributions linked to $E^{*}$ and assess them to taxation, ignoring other income during retirement. However, as the 
schedules of personal income taxes are progressive, this procedure would result in too small tax payments, and $E_{p}$ would appear too high. Therefore, we determine $E_{p}$ in two steps. In the first step, the tax rate applying to this employee's total pension income is derived. In the second step, the pension resulting from contributions during period $t_{0}$ is determined. Subtracting from this pension taxes according to the tax rate derived in the first step then yields disposable income $E_{p}$.

In order to obtain the tax rate, the annual pension income that results from the contributions during the entire working life has to be computed and then assessed to personal income tax according to tax regulations. This pension consists of annual payments $\tilde{\Pi}$ received from the first pillar of old-age insurance, and an annuity $\tilde{A}$ received from occupational pension plans. For both kinds of pensions, we assume constant contributions during working life amounting respectively to $\Omega$ and $C$ per year.

The public pension $\tilde{\Pi}$ is calculated according to the country-specific pension formulae currently in force which often depend on the number of years during which the employee has worked and paid into social insurance. The occupational pension $\tilde{A}$ is calculated as an investment under market conditions. The invested contributions result in a capital stock at the end of working life. The capital is then distributed over all $P$ years of retirement as an annuity which is the annual pension $\tilde{A}$. Formally, $\tilde{A}$ is obtained from equating the value of contributions and of pension claims at the beginning of the retirement phase:

$$
\sum_{t=0}^{t_{p}-1} C(1+\hat{r})^{t_{p}-t}=\sum_{t=t_{p}}^{t_{p}+P-1} \frac{\tilde{A}}{(1+\hat{r})^{t-t_{p}}}
$$

The left-hand-side of equation (11) is the capital stock accumulated by the occupational pension plan during the working years $t=0,1, \ldots, t_{p^{-}}-1$, valued at the beginning of retirement in period $t_{p}$. The right-hand-side of (11) is the present value at time $t_{p}$ of a stream of annuities $\tilde{A}$ received by the retired employee throughout the retirement phase, that is in periods $t=t_{p}, t_{p}+1, \ldots, t_{p}+P$-1. In (11) the interest rate $\hat{r}$ relevant for the company's payment into the occupational pension scheme is used, taking account of the tax treatment of these payments on the company level.

Adding both annuities and subtracting deductions $d_{p}$ applying to the retired employee, for example due to a favourable treatment of income from public pensions, one arrives at the taxable income in each year of retirement. Denoting personal characteristics in the retirement phase by $x_{p}$ the tax payment $T\left(\tilde{\Pi}+\tilde{A}-d_{p}, x_{p}\right)$ results. Dividing this by the pension income gives the average tax rate

$$
\tau_{p}=\frac{T\left(\tilde{\Pi}+\tilde{A}-d_{p}, x_{p}\right)}{\tilde{\Pi}+\tilde{A}}
$$

during each year of retirement.

In the second step, the pension is calculated that would result exclusively from the contributions paid out of the total remuneration relating to period $t_{0}$. For occupational 
pensions, this implies that contributions $C$ are invested in period $t_{0}$ and the resulting capital stock at time $t_{p}$ is then distributed as annuities $A$ over all years of retirement. That is, $A$ is determined by

$$
C(1+\hat{r})^{t_{p}-t_{0}}=\sum_{t=t_{p}}^{t_{p}+P-1} \frac{A}{(1+\hat{r})^{t-t_{p}}}
$$

For the public pension, we assume that $€ 1$ of contributions increases the pension by the same amount, no matter when it was paid. Together with the assumption of a constant stream of contributions, and noting that the working phase $t=0,1, \ldots, t_{p}-1$ is of length $t_{p}$, this implies that the public pension linked to total remuneration $E^{*}$ is equal to

$$
\Pi=\frac{\tilde{\Pi}}{t_{p}}
$$

In order to obtain the disposable income $E_{p}$ of one period during retirement, the sum of both kinds of annual pensions according to (13) and (14) has to be reduced by taxes according to the tax rate given in (12). We so arrive at

$$
E_{p}=\left(1-\tau_{p}\right) \cdot(\Pi+A) .
$$

Thus, with equations (10) and (15), all elements for computing the EATR according to (1) and (2) are in place.

The effect of interest rates.

When calculating the disposable income during retirement, at two instances, interest rates are important. Firstly, the firm may face a different interest rate after taxes than the employee. This will arise, for example, when the employee has to pay tax on interest income while the firm can accumulate tax-free, since investments into pension funds are tax-deductible. If this is the case, it is more advantageous to save inside the company in the form of an occupational pension scheme rather than to save on the household level. Secondly, the formula used to calculate the public pension will exhibit an internal rate of return which typically differs, and most of the time falls short of the market interest rate. Thus, contributions to the first pillar of old-age insurance usually are dominated by private savings. The loss of return compared to the market interest rate is equivalent to a tax implicit in the obligation to pay into compulsory pay-as-you-go pension systems.

\section{International comparison}

The following analysis shows the effective average tax rates on highly qualified manpower in Germany, France, the UK, and the USA (Massachusetts). In all simulations, we refer to legislation in force in 2003 . We measure the tax burden that occurs under varying conditions in context with the employee's characteristics (income level, compensation package, and family situation) and in context other variables (interest rate before and after taxes, exchange rates). In the analysis, we consider all personal in- 
come taxes, surcharges (in Germany), as well as payroll taxes (in France). We define as charges the contributions to insurances against unemployment and work-related injury, and the charges in France concerning apprentices, advancement of employment and housing, as well as the social tax. In the UK, where a social security system with overall contributions applies, we assume that one fifth of all contributions up to the employee's income ceilings and all exceeding contributions are comparable to a charge. ${ }^{5}$

\section{Results for a single employee.}

In the standard case, we analyse a single employee without children. His total remuneration consists of 80 per cent cash compensation and 20 per cent old-age provision. Employer and employee contribute equal shares to the second pillar of old-age insurance. Considering first the benchmark case of a disposable income after taxes and charges of $€ 100,000$, we obtain effective average tax rates of 39.0 per cent in the USA, 40.9 per cent in the UK, 48.9. per cent in Germany, and 49.0 per cent in France. In other words, employers in France have to incur expenses of $€ 196,078$ to compensate their highly skilled employees with a disposable income of $€ 100,000$. Employers in the USA only have to pay $€ 163,934$ to grant the same disposable income. With increasing income, EATRs are increasing as well (see table B-1). Figure 4-1 shows the effective tax burden when the disposable income increases from $€ 40,000$ to $€ 200,000$. In Germany, the EATR increases by 4.8 percentage points. In the USA, France, and the UK, the EATRs increase by $10.0,12.9$, and 13.5 percentage points, respectively.

These results reflect top statutory income tax rates and the size of income brackets in which lower tax rates apply. In addition, EATRs are determined by contribution rates and income ceilings of social insurance. We discuss the tax schedules first. In Germany, the highest tax rate of 51.2 per cent ${ }^{6}$ applies for incomes of more than $€ 50,000$. In France, the top tax rate of 49.58 per cent applies to income exceeding $€ 47,000$. In the UK and the USA, the top tax rates are at least five percentage points below the German and French rates: They amount to 40 per cent and 43.9 per cent ${ }^{7}$ respectively. These rates are achieved with incomes of $£ 29,900$ and $\$ 311,950$ respectively. Thus, the high EATR in Germany and France is clearly a consequence of the high statutory tax rate. On the other hand, in the USA, the incomes considered do not yet fall in the highest bracket. For example, the highest tax rate applicable to a taxable income of $\$ 130,000$ is 30 per cent. Hence, the EATR in the standard case with a disposable income of $€ 100,000$ is substantially below the top tax rate.

If, in Germany, taxable income exceeds $€ 50,000$ the highest tax rate is applied to the entire taxable income, with the resulting tax liability being reduced only by a tax deduction of $€ 9,000$. In the other countries analysed, the tax schedule assigns different tax rates to each income bracket. While this is formally equivalent to a proportional schedule combined with a tax deduction, as in the German case, the resulting tax relief is much larger in the three other countries. Therefore, the progressiveness of the per-

\footnotetext{
${ }^{5}$ See tables A-1 to A-5 in the appendix for more details.

${ }^{6}$ Including surcharge of 5.5 per cent of top income tax rate of 48.5 per cent in 2003 .

${ }^{7}$ Combined tax rate of Federal Income Tax and personal income tax of the state of Massachusetts.
} 
sonal income tax is more pronounced in these countries than in Germany, despite the fact that in the UK and in France the top tax rate is achieved with comparable levels of income.

Figure 4-1: Effective average tax rate with varying disposable incomes of a single (2003)

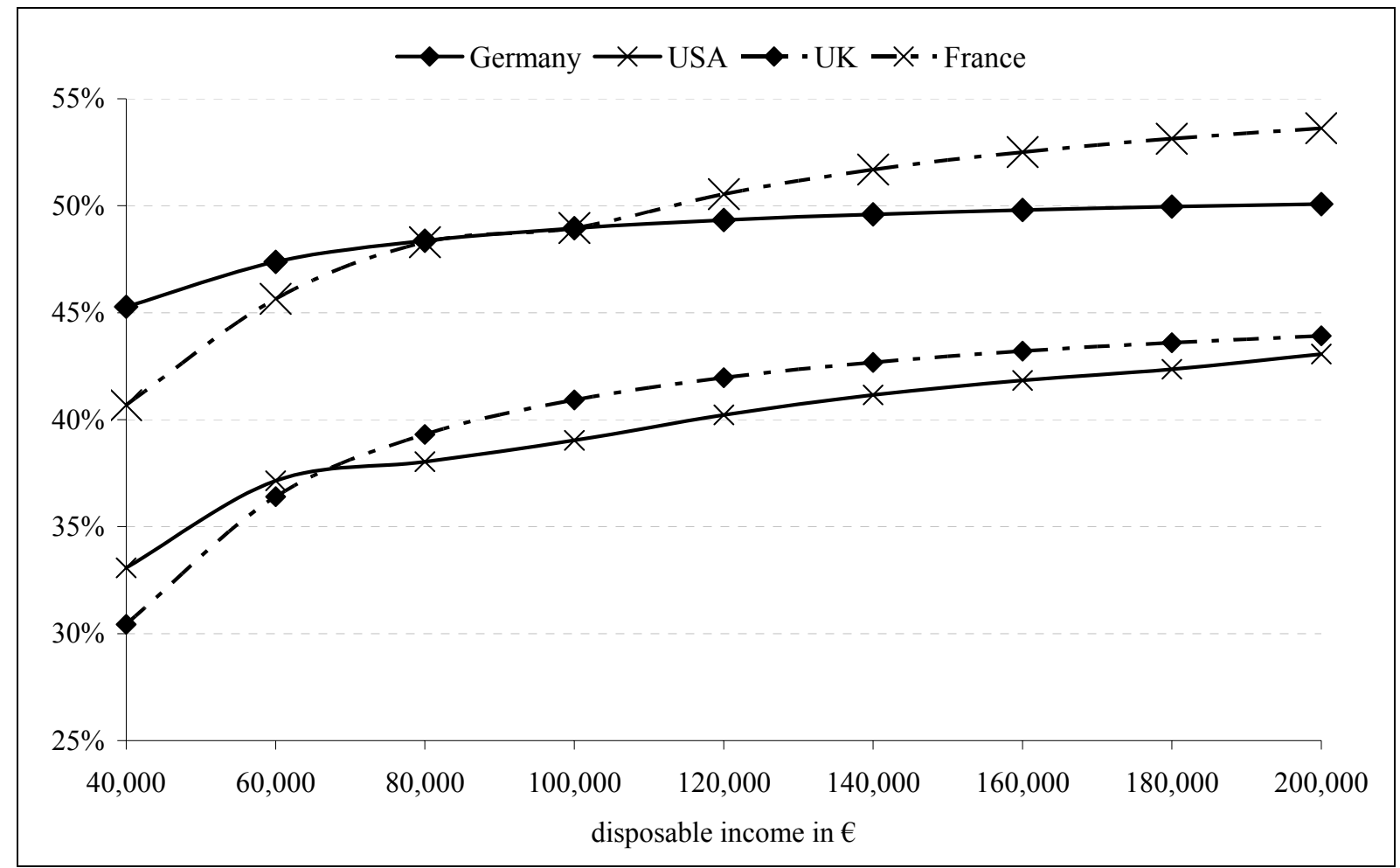

Source: ZEW

The contribution rates to the social insurance systems considered as charges in our simulation vary substantially, between 3.3 per cent in the UK and around 18 per cent including social tax in France. In France tax-like social security contributions have thus a remarkable influence on the tax burden, which is however mitigated somewhat by generous deductions for social security contributions and work related expenses. In the USA and in Germany, all contributions are limited by moderate income ceilings. In France, to the contrary, contributions and social tax of 13 per cent have to be paid on the entire income. In the UK, the employer's contributions are payable on total income. In the two latter countries, the proportion of charges relative to income stays therefore constant whereas in Germany and in the USA, the importance of social security and tax-like charges decreases with increasing income. This, together with the income tax schedule, explains the moderate rise in EATRs in Germany as opposed to the fairly steep increase in the other three countries.

\section{Family taxation.}

Families receive several tax allowances in all countries. One kind of tax relief for families consists of allowances for married couples, usually in the form of joint filing and special tax schedules. The other kind of relief is granted in the form of tax allowances or transfer payments for dependent children. A common way of taxing couples is to divide their joint income by a "family quotient" and determining the average statutory tax rate applicable to a single who earns this reduced income. This tax rate is 
then applied to the couple's joint income. Given increasing average tax rates, for a couple with differing incomes, this procedure results in lower tax payments compared to a single earning the joint income of both spouses. In Germany, the quotient is 2 , irrespective of the number of children. In France, the quotient is 3 for a family of four, ${ }^{8}$ but the advantage procured by this quotient compared to a quotient of 2 is limited to $€ 4,100$. The USA does not apply a family quotient but subjects married couples to a special tax schedule instead. In the highest income bracket, however, this special schedule provides for the same tax rate as the schedule for singles. The UK does not grant joint filing, i.e., each spouse is subject to tax with her or his individual income.

Transfer payments for two children amount to $€ 2,600$ in France, $€ 3,700$ in Germany, and $£ 1,300$ in the UK. In addition, children are taken into account for the calculation of the tax payment in France in the form of a higher family quotient as explained, and in the form of a child tax credit for lower incomes in the UK. In Germany, families can deduct $€ 11,600$ from taxable income if this form of child allowance is preferable to the transfer payment. The USA grants personal deductions of $\$ 3,050$ for each family member and a child tax credit of up to $\$ 600$ for low earnings.

Considering the tax regulations one observes that Germany seems to be the country favouring families most. This impression is confirmed by our simulations. With respect to the EATRs of families, the ranking of the countries analysed changes compared to the case of singles (see tables B-2 and B-3). In Germany, the employer has to spend much less for a highly qualified employee with a family than for a single if he wants to grant a disposable income of $€ 40,000$. With an EATR of 20 per cent, Germany in this case has the second lowest tax burden behind the USA with 19.6 per cent. In the UK, the EATR is 24.8 per cent and in France, it is 29.3 per cent. For higher incomes, the ranking changes again. For income levels of $€ 200,000$ we observe the same ranking as for singles.

Figure 4-2 illustrates the family advantage by displaying the ratio of the EATR of a family over the EATR of a single with the same disposable income. In Germany, this ratio is lowest, i.e., the family advantage is highest. The ratio is 44.1 per cent for a family receiving a disposable income of $€ 40,000$. The family advantage decreases for higher incomes up to a ratio of 89.6 per cent for a disposable income of $€ 200,000$. The USA also favour families to a relatively high extent for lower incomes, and at a level comparable to France for higher incomes. In the UK, the family advantage resulting from child allowances decreases rapidly with increasing income leaving virtually no family benefit at an income of $€ 200,000$. The reason why we find such a high family advantage in Germany is the high level of child allowances respectively child credits and the unlimited advantage of joint filing for married couples.

\footnotetext{
${ }^{8}$ For each spouse, 1 is added to the quotient, and for each dependent child, the quotient is raised by 0.5 .
} 
Figure 4-2: Family advantage: a family's EATR divided by a single's EATR (2003)

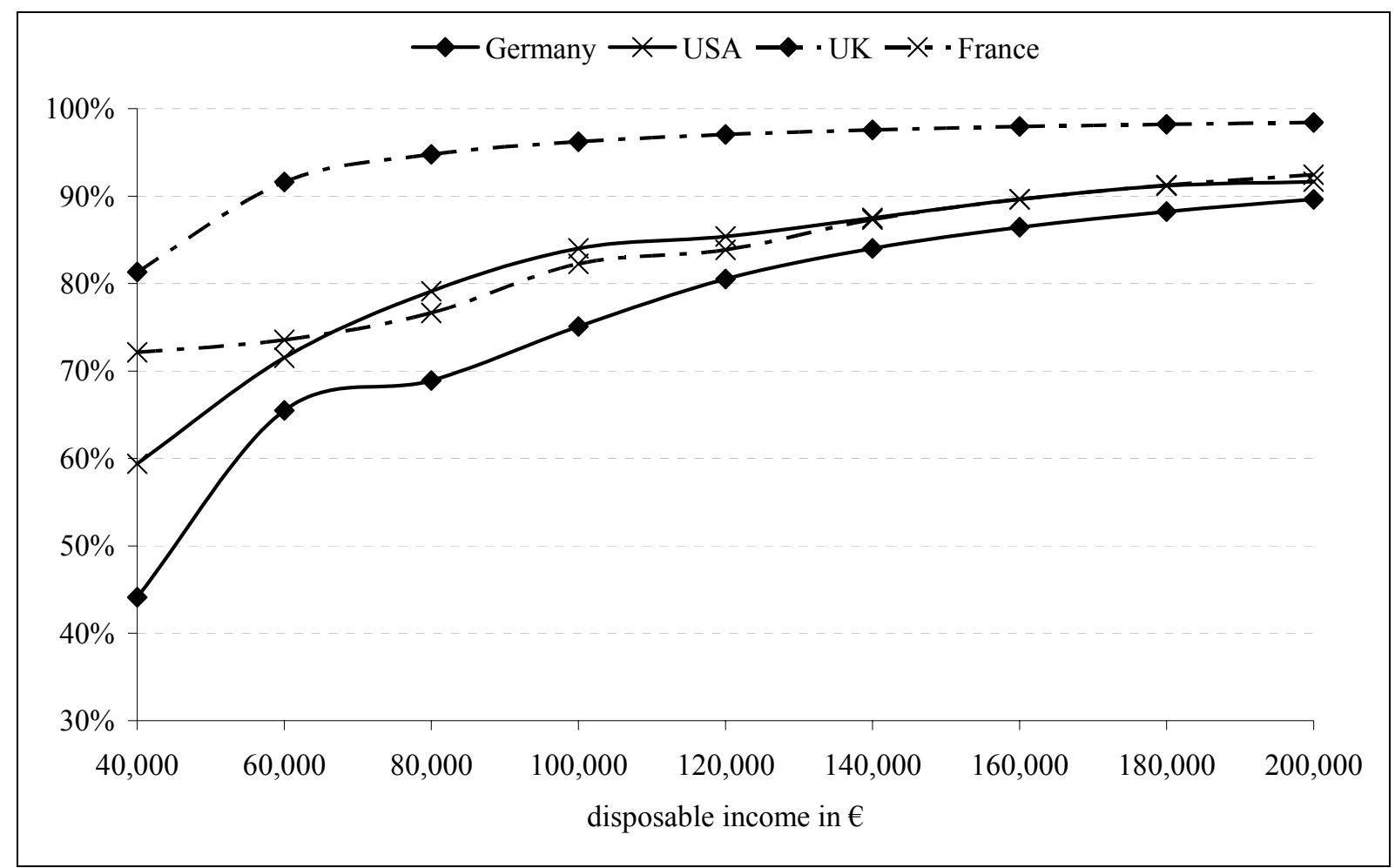

Source: ZEW

The effect of exchange rates.

The cost of living does not differ substantially in the countries analysed. Because of this, we transfer the disposable income expressed in $€$ to $\$$ respectively $£$ by average nominal exchange rates (see table A-5). Taking into account different costs of living, another possibility to convert the disposable income is using purchasing power parities like those published by the OECD. The purchasing power parities (PPP) are measured as the amount of local currency necessary to buy the same basket of goods which costs $\$ 1$ in the USA. France has a PPP of 0.912, Germany 0.981 and UK 0.638 in 2003. If one converts the disposable income using the purchasing power parities of the OECD the EATRs only change to a small extent (see table B-4). The tax burdens increase by 0.1 percentage points in the UK and 0.5 percentage points in the USA.

\section{Taxation of old-age provision.}

The composition of the compensation package also influences the effective average tax rates. In principle, deferring compensation to the retirement phase may be favourable or detrimental because of two kinds of effects: The interest effect arises because personal income taxes on interest income drive a wedge between the interest rates before and after taxes. Schedule effects stem from the schedules of income taxes and social security. A progressive tax schedule implies a lower average tax rate if compensation is transferred into a period (typically the pension period) in which the total income is lower. Furthermore, the compensation package may influence the base used to compute the contributions to social security. However, it turned out that schedule effects are less important in our simulations than the interest effect because of the high level of income analysed. 
To illustrate the working of the interest effect we simulate two scenarios. In the first scenario, we assume that the employee's interest rate after taxes $\bar{r}$ equals the interest rate relevant for the company $\hat{r}$ and also the market interest rate. This means that interest income derived from a hypothetical alternative investment is tax free. Compared to this investment the taxation of contributions into old-age provision is neutral if either contributions are fully deductible and pensions are taxed, or conversely, contributions are not deductible and pensions are tax free. In the second scenario, we consider the other extreme where the interest income derived from the alternative investment is subject to the top marginal income tax rate whereas the return on investment by the company remains tax free. That is, in this scenario, we have $\bar{r}<\hat{r}$ and $\hat{r}$ equals the market interest rate. In this case, a neutral taxation of pensions is achieved if contributions are not deductible and only the income element, that is the interest implicit in the pension payment, is subject to taxation.

Turning to the case $\bar{r}=\hat{r}$ first, we compute the EATR for different compositions of the compensation package for the disposable income of $€ 100,000$. For that purpose, we vary the share of old-age provision, which is composed of contributions to the first and the second pillar of old-age insurance, from 15 to 45 per cent. Notice that we have to assume a certain minimum amount of old-age provision because contributions to the first pillar are compulsory.

Table 4-1: The effective tax burden with variation of old-age provision in the case $\bar{r}=\hat{r}$, single, disposable income $€ 100,000$, in \%

\begin{tabular}{ccccc}
\hline \hline $\begin{array}{c}\text { Proportion old-age provi- } \\
\text { sion }\end{array}$ & France & Germany & UK & USA \\
\hline $15 \%$ & 48.0 & 49.0 & 40.2 & 38.2 \\
$20 \%$ & 49.0 & 48.9 & 40.9 & 39.0 \\
$25 \%$ & 49.9 & 48.9 & 42.0 & 39.9 \\
$30 \%$ & 50.9 & 48.9 & 43.0 & 40.9 \\
$35 \%$ & 52.0 & 48.9 & 44.0 & 41.9 \\
$40 \%$ & 53.2 & 48.9 & 45.1 & 43.0 \\
$45 \%$ & 54.3 & 48.9 & 46.1 & 44.0 \\
\hline \hline
\end{tabular}

Source: ZEW

As is apparent from table 4-1, increasing the part of old-age provision in the compensation package produces diverging effects on the EATR in the four countries. The effective tax burden nearly stays constant in Germany. In the German case we assume that occupational pensions are granted in the form of a direct guarantee. This implies that contributions to the second pillar by both employer and employee ${ }^{9}$ are tax exempt during investment and that pensions are taxable income during retirement. ${ }^{10}$ Thus, in

\footnotetext{
${ }^{9}$ In the case of a direct guarantee, the employee's contribution consists of foregoing cash compensation in exchange for the pension claim.

${ }^{10}$ For an analysis of the taxation of different forms of old-age provision in Germany, see Brassat and Kiesewetter (2003).
} 
Germany the tax system treats occupational pensions like a hypothetical investment whose interest is tax free.

In France, the tax burden increases by 6.3 percentage points when the proportion of old-age provision increases from 15 to 45 per cent. The employee's and employer's contributions to the voluntary second pillar usually are subject to tax. Consequently, a neutral taxation in the first scenario would imply that all resulting pensions are taxexempt. However, in France these pensions are taxable with a standardised income element of 40 per cent. Thus, there is a discriminating interest effect.

In the UK, contributions to occupational pension plans are deductible up to 15 per cent of gross income with an annual ceiling of $£ 97,200$. Exceeding contributions are not deductible. Resulting pensions always are subject to tax, even if the contributions have been paid out of taxed income. Thus, with an increasing proportion of old-age provision the effective tax rate increases by 5.9 percentage points, because an increasing proportion of old-age provision is double-taxed.

In the USA, contributions paid by the employer are tax exempt and the resulting pensions are taxable during retirement. Contrary to that, contributions paid by the employee are not deductible in the remuneration period, but the resulting pensions are still taxable with their income element. Compared to the hypothetical tax-free investment, this results in a non-neutral taxation of old-age provision which explains why the EATR increases by 5.8 percentage points.

Table 4-2: The effective tax burden with variation of old-age provision in the case $\bar{r}<\hat{r}$, single, disposable income $€ \mathbf{1 0 0 , 0 0 0}$, in \%

\begin{tabular}{ccccc}
\hline \hline $\begin{array}{c}\text { Proportion old-age provi- } \\
\text { sion }\end{array}$ & France & Germany & UK & USA \\
\hline $15 \%$ & 41.6 & 41.0 & 35.1 & 29.8 \\
$20 \%$ & 37.5 & 37.7 & 32.7 & 27.2 \\
$25 \%$ & 31.9 & 34.4 & 30.5 & 24.6 \\
$30 \%$ & 26.3 & 31.1 & 28.3 & 22.1 \\
$35 \%$ & 20.7 & 27.8 & 26.2 & 19.7 \\
$40 \%$ & 15.1 & 24.6 & 24.0 & 17.4 \\
$45 \%$ & 9.5 & 21.3 & 21.8 & 15.2 \\
\hline
\end{tabular}

Source: ZEW

In the second scenario with $\bar{r}<\hat{r}$, the company's interest rate remains the market rate of return, whereas the employee's net interest rate $\bar{r}$ is calculated from the market interest rate by taking into account the country-specific top marginal tax rate including surcharges and state taxes. In this case, it pays off in all countries to defer compensation into the future by old-age provision, as shown in table 4-2. The tax burdens fall with increasing old-age provision by 13.3 percentage points in the UK, 14.6 percentage points in the USA, 19.7 percentage points in Germany, and 32.1 percentage points in France. 
In this case, contributions are invested at a higher interest rate than the interest rate with which the resulting pension payments are evaluated. Consequently, if contributions are not deductible, a neutral taxation would require subjecting the income element to tax. If contributions are deductible, a neutral taxation of old-age provision is possible only if the entire pension is taxed at a rate which exceeds the tax rate during the remuneration period. As the preceding discussion shows, in all the countries analysed the taxation of old-age provision is favourable compared to this neutrality benchmark. This is most evident in the case of France. Here, a certain schedule effect arises because high old-age provision reduces the base for contributions to the compulsory pension system. Furthermore the high marginal tax rate increases the wedge between the gross and the net interest rate thereby enhancing the interest effect.

\section{Conclusions}

This paper aims at quantifying the effective average tax rate (EATR) of highly skilled employees from an employer's point of view. We measure the employer's expenses for a highly qualified employee under the assumption that the highly qualified has to obtain an internationally comparable disposable income after taxes. We consider income taxes including surcharges, tax-like social security contributions as well as payroll taxes paid by the company. The employee's income is assessed for tax and social security purposes in several periods during the life cycle. Using this method, we derive EATRs for several income levels, structures of compensation, and family situations which are typical for highly qualified employees.

The results show that there are considerable differences in tax burden across the countries studied. The USA and the UK most of the time have lower tax burdens than Germany and France. Considering families, Germany moves up to the second rank. The EATR increases with increasing income despite income ceilings for social security, as all tax systems considered have progressive tax schedules.

The main tax drivers for the tax burden on highly skilled labour are the tax rate of the personal income tax and income ceilings and contribution rates to social security. Especially with lower incomes the employee's family situation is important for the tax burden. The composition of the compensation package has a minor influence on the tax burden if one compares old-age provision with a hypothetical investment yielding tax free interest. If such interest income is taxed at the top marginal rate of the personal income tax, however, the EATR can be reduced substantially by increasing the share of occupational pension plans in the compensation package.

Our analysis suggests two main lines for future research. Firstly, the model can be extended and applied in several ways. Obviously, from a policy perspective, a larger geographical scope than the four countries analysed would be informative. Also, more variation of the family situation and the compensation package will provide deeper understanding of the working of tax and social security regulations. ${ }^{11}$ While the cur-

\footnotetext{
${ }^{11}$ See Elschner and Schwager (2004a) and Elschner and Schwager (2004b) for an extension to nine countries and the inclusion of other compensation components such as stock option plans.
} 
rent paper provides an international comparison, it does not deal with genuinely international transactions. Therefore, a major structural extension will consist of integrating the taxation of expatriate staff into the model. A different issue which in principle could be modelled with our approach is the taxation of employees who change residence when they retire.

Secondly, the results of our simulation model can serve as an input into empirical research projects which aim at testing the impact of taxes on other economic variables. For example, our simulation results may be used to assess empirically the impact of the taxation of highly qualified employees on regional growth rates or on migration flows. 


\section{Appendix}

\section{A Tax and Social Security Regulations}

\section{Table A-1: Social insurance}

\begin{tabular}{|c|c|}
\hline Germany & \\
\hline $1^{\text {st }}$ pillar old-age insurance & $\begin{array}{l}\text { - contribution rate: } 9.75 \% \text { (each, employee and employer) } \\
\text { - income ceiling: } € 62,100\end{array}$ \\
\hline Health insurance & $\begin{array}{l}\text { - contribution rate: about } 7 \% \text { (each, employee and employer) } \\
\text { plus care insurance } \\
\text { - } \\
\text { income ceiling: } € 41,400 \\
\text { liable for contributions with income up to } € 45,900\end{array}$ \\
\hline Unemployment insurance & $\begin{array}{l}\text { - contribution rate: } 3.25 \% \text { (each, employee and employer) } \\
\text { - income ceiling: } € 62,100\end{array}$ \\
\hline Work injury insurance & $\begin{array}{l}\text { - contribution rate: about } 1.42 \% \text { (employer) } \\
\text { - income ceiling: } € 61,356\end{array}$ \\
\hline France & \\
\hline $1^{\text {st }}$ pillar old-age insurance & $\begin{array}{l}\text { contribution rate employee: } 6.55 \% \text { up to income of } € 29,184 \\
\text { contribution rate employer: } 8.2 \% \text { up to income of } € 29,184 \\
\text { contribution rate employee: } 0.1 \% \text { without income ceiling } \\
\text { contribution rate employer: } 1.6 \% \text { without income ceiling }\end{array}$ \\
\hline Health insurance & $\begin{array}{l}\text { - contribution rates: } 0.75 \% \text { (employee), } 12.8 \% \text { (employer) } \\
\text { - no income ceiling }\end{array}$ \\
\hline Unemployment insurance & $\begin{array}{l}\text { - } \quad \text { contribution rate: } 2.1 \% \text { (employee), } 4 \% \text { (employer) } \\
\text { - } \quad \text { income ceiling: } € 29,184\end{array}$ \\
\hline Work injury insurance & - $\quad$ contribution rate: about $2.26 \%$ (employer) \\
\hline Other $\mathrm{c}$ & $\begin{array}{l}\text { charges concerning apprentices, advancement of employ- } \\
\text { ment, housing: contribution rate } 5.4 \% \text { (employer) } \\
\text { social tax (Contribution sociale généralisée CSG and Contri- } \\
\text { bution au remboursement de la dette sociale CRDS): contri- } \\
\text { bution rate } 8 \% \text { on } 95 \% \text { of gross income (employee) }\end{array}$ \\
\hline UK & \\
\hline $\begin{array}{l}\text { Global insurance/overall } \\
\text { contributions }\end{array}$ & $\begin{array}{l}\text { - contribution rate employee: } 8.4 \% \text { on income up to } £ 30,420 \\
\text { - contribution rate employer: } 8.3 \% \text { starting on income above } \\
£ 4.615 \text { without income ceiling (contracted-out) }\end{array}$ \\
\hline USA & \\
\hline $1^{\text {st }}$ pillar old-age insurance & $\begin{array}{l}\text { - contribution rate } 6.2 \% \text { (each, employer and employee) } \\
\text { - income ceiling: } \$ 87,000\end{array}$ \\
\hline Health insurance & $\begin{array}{l}\text { - contribution rate } 1.45 \% \text { (each, employer and employee) } \\
\text { - no income ceiling }\end{array}$ \\
\hline Unemployment insurance & $\begin{array}{l}\text { - contribution rate: } 6.2 \% \text { (employer) } \\
\text { - income ceiling: } \$ 7,000\end{array}$ \\
\hline Work injury insurance & - contribution rate: variable, average in 1995 at $2.05 \%$ \\
\hline
\end{tabular}




\section{Tax System:}

\section{Table A-2: Kinds of taxes analysed}

\begin{tabular}{lll}
\hline \hline Germany & - & personal income tax \\
& - & surcharge (Solidaritätszuschlag) $5.5 \%$ of personal income tax \\
France & - & personal income tax \\
& - & lump sum tax (taxe professionnelle) \\
UK & - & personal income tax \\
USA & - & federal income tax \\
& - & state income tax \\
\hline
\end{tabular}

\section{Table A-3: Personal income tax: allowances and schedules}

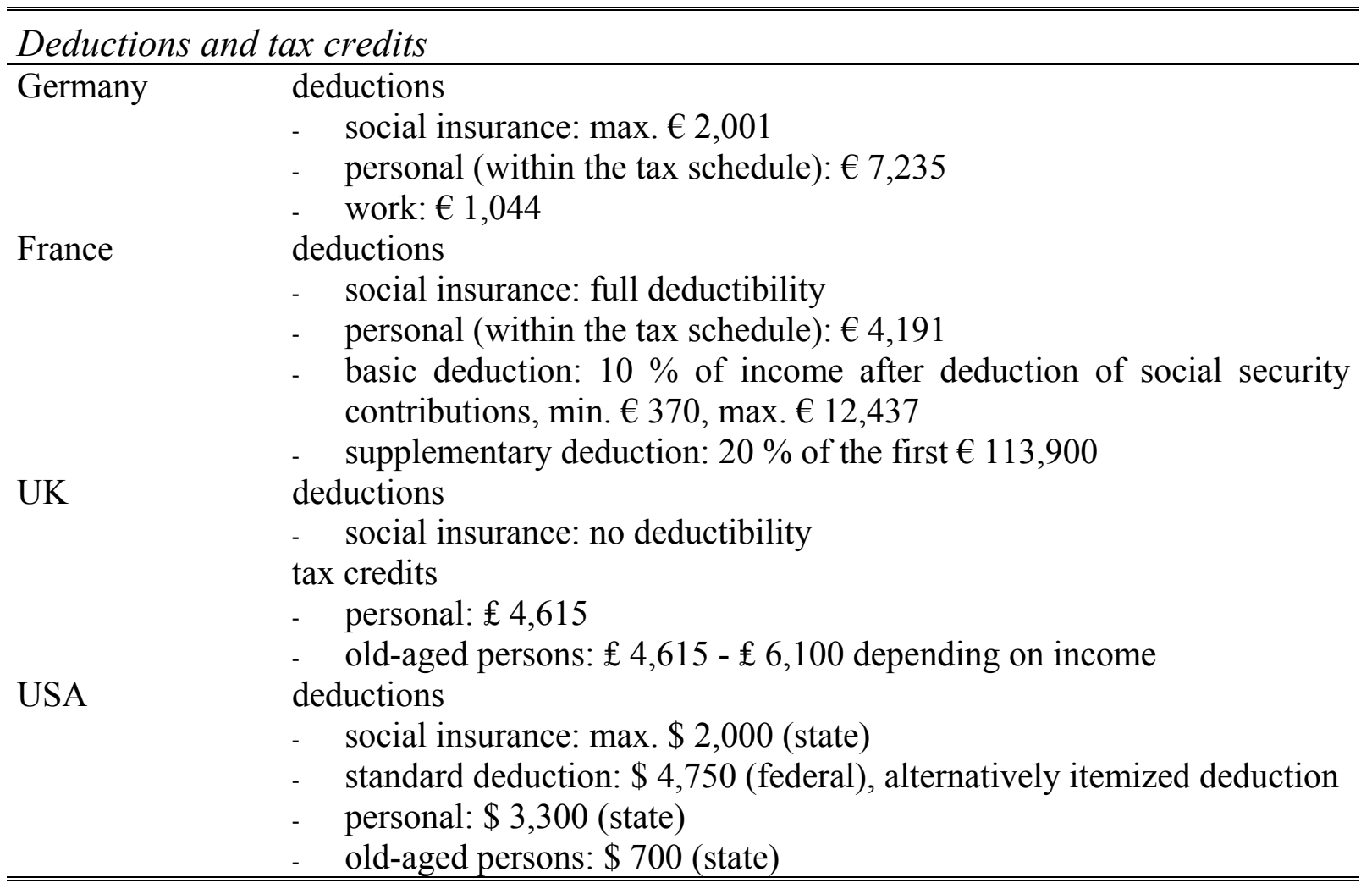

\section{Tax schedules}

Germany

Single

\begin{tabular}{cc} 
taxable income in $€$ & tax formula \\
\hline up to 7,235 & 0 \\
$7,236-9,251$ & $(768.85 \cdot \mathrm{y}+1,990) \cdot \mathrm{y}$ \\
& $\mathrm{y}=1 / 10,000 \cdot($ taxable income $-7,200)$ \\
$9,252-55,007$ & $(278.65 \cdot \mathrm{z}+2,300) \cdot \mathrm{z}+432$ \\
& $\mathrm{z}=1 / 10,000 \cdot($ taxable income $-9,216)$ \\
from 55,008 on & $0.485 \cdot \mathrm{x}-9,872$ \\
& $\mathrm{x}=$ taxable income
\end{tabular}

Married couples quotient: 2 


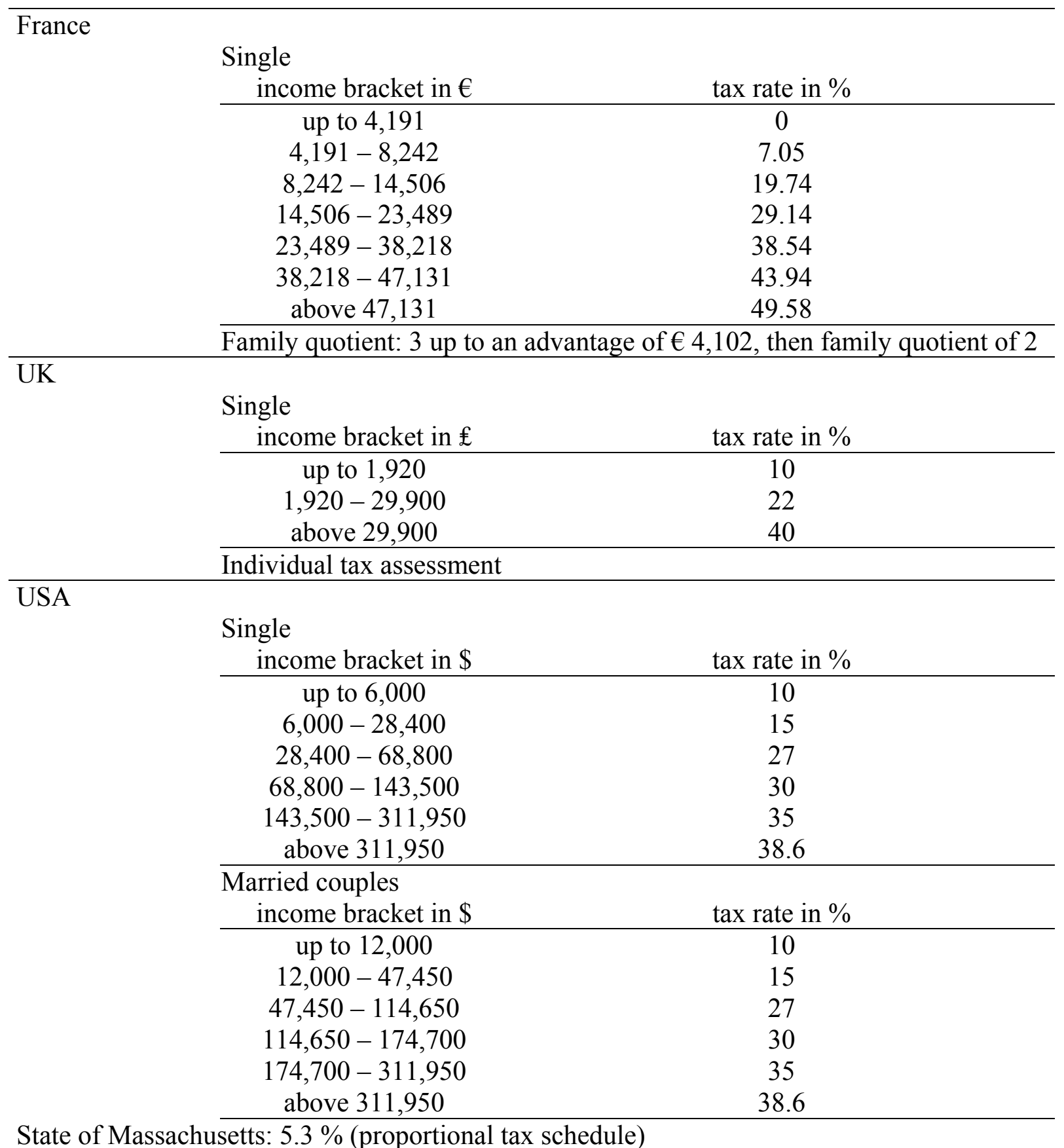

tax schedule) 
Table A-4: Old-age provisions: first and second pillar of old-age insurance and tax regulations

First pillar

Contributions see above

Pension formula for a monthly public pension after 40 years of contributions

Germany pension points $\bullet$ current pension value pension points: 1.8 per year of contributions. pension value in 2003: 26.13

France $\quad$ reference income $\bullet$ individual pension factor $\bullet$ number of insurance quarters reference income: average of earnings. pension factor: 0.5 for a person retiring at the age of 65

UK currently $£ 290$

USA average income $\bullet$ discount factor discount factor for the first \$ 593: $90 \%$, for the next \$ 2,975: $32 \%$, exceeding parts: $15 \%$

Taxation of contributions: see above

Taxation of public pensions

Germany income element taxable (27\% for a person retiring at the age of 65 )

France fully taxable

UK fully taxable

USA fully taxable with incomes above $\$ 43,000$

Second pillar

Type of occupational old-age provision

Germany Direct guarantee. Employee's contributions are deferred compensation.

France Compulsory contributions to Agirc and Arrco between 7.5 and $20 \%$ of defined income brackets; financed as PAYG-systems; pension formula: summarised pension points · pension value, pension point is the annual contribution divided by a reference income.

Non-compulsory contributions are invested in additional pension schemes.

UK Pension Plan (defined-contribution). Resulting annual pension payment must not exceed the maximum benefit of two thirds of the final remuneration to be tax-privileged.

USA Pension Plan. Contributions must not exceed $25 \%$ of the employee's earnings or $\$ 35,000$ per year.

Taxation of contributions

Germany Employer's contributions are tax exempt. Employee's contributions are tax exempt as the employee does not obtain a legal claim to a future pension.

France Employer's and employee's contributions are tax-exempt/tax-deductible up to a limit of $19 \%$ of 8 times the income ceiling of social insurance.

UK Employer's contributions are tax exempt. Employee's contributions are tax exempt up to $15 \%$ of gross income with an annual maximum of $£ 97,200$.

USA Employer's contributions are tax exempt. Employee's contributions are subject to tax. 


\section{Taxation of pensions}

Germany Pension payments out of direct guarantees are fully taxable. A tax allowance of $40 \%$ of the pension, maximum $€ 3,072$, can be claimed.

France Pensions out of compulsory system are subject to tax. Annuities resulting from non-compulsory pension plans are taxable with their income element of $40 \%$.

UK Pensions are fully taxable.

USA Pensions resulting from the employer's contributions are fully taxable. Pensions resulting from the employee's contributions are taxable with their income element: The employee's total contributions to the occupational pension plan are divided by the total number of expected monthly annuities. The ratio divided by the number of annuities is the monthly tax exempt amount of occupational pension.

\section{Table A-5: Exogenous variables}

\begin{tabular}{ll}
\hline \hline$r$ & market interest rate 5 per cent \\
exchange rates & average nominal exchange rates in 2003 \\
& $\$$ to $€: 1.1294 ; £$ to $€: 0.6915$ \\
PPP & Purchasing Power Parities \\
& $\$$ to $€$ (average of France and Germany): $1.0565 ; £$ to $€$ (average \\
& of France and Germany): 0.6741 \\
number of years in work & 40 \\
number of years during retirement & 20 \\
$f_{c}$ & fraction cash compensation 80 per cent in the standard case \\
$f_{p}$ & fraction old-age provision 20 per cent in the standard case \\
\hline \hline
\end{tabular}

\section{B Results in Detail}

Table B-1: The effective tax burden with variation of disposable income, single, in $\%$

\begin{tabular}{ccccc}
\hline \hline Disposable income in $€$ & France & Germany & UK & USA \\
\hline 40,000 & 40.7 & 45.3 & 30.4 & 33.1 \\
60,000 & 45.6 & 47.4 & 36.4 & 37.1 \\
80,000 & 48.3 & 48.4 & 39.3 & 38.0 \\
100,000 & 49.0 & 48.9 & 40.9 & 39.0 \\
120,000 & 50.5 & 49.3 & 42.0 & 40.2 \\
140,000 & 51.7 & 49.6 & 42.7 & 41.2 \\
160,000 & 52.5 & 49.8 & 43.2 & 41.8 \\
180,000 & 53.1 & 50.0 & 43.6 & 42.4 \\
200,000 & 53.6 & 50.1 & 43.9 & 43.1 \\
\hline \hline
\end{tabular}


Table B-2: The effective tax burden with variation of disposable income, family, in $\%$

\begin{tabular}{ccccc}
\hline \hline Disposable income in $€$ & France & Germany & UK & USA \\
\hline 40,000 & 29.3 & 20.0 & 24.8 & 19.6 \\
60,000 & 33.6 & 31.0 & 33.4 & 26.6 \\
80,000 & 37.0 & 33.3 & 37.3 & 30.1 \\
100,000 & 40.3 & 36.8 & 39.4 & 32.8 \\
120,000 & 42.4 & 39.7 & 40.7 & 34.3 \\
140,000 & 45.1 & 41.7 & 41.6 & 36.0 \\
160,000 & 47.1 & 43.0 & 42.3 & 37.5 \\
180,000 & 48.5 & 44.1 & 42.8 & 38.6 \\
200,000 & 49.6 & 44.9 & 43.2 & 39.5 \\
\hline
\end{tabular}

Source: ZEW

Table B-3: The family advantage: a family's EATR divided by a single's EATR, in $\%$

\begin{tabular}{ccccc}
\hline \hline Disposable income in $€$ & France & Germany & UK & USA \\
\hline 40,000 & 72.1 & 44.1 & 81.3 & 59.4 \\
60,000 & 73.6 & 65.5 & 91.6 & 71.5 \\
80,000 & 76.6 & 68.9 & 94.8 & 79.1 \\
100,000 & 82.3 & 75.1 & 96.2 & 84.0 \\
120,000 & 83.9 & 80.5 & 97.0 & 85.4 \\
140,000 & 87.3 & 84.0 & 97.6 & 87.5 \\
160,000 & 89.6 & 86.4 & 97.9 & 89.6 \\
180,000 & 91.3 & 88.2 & 98.2 & 91.2 \\
200,000 & 92.4 & 89.6 & 98.4 & 91.7 \\
\hline \hline
\end{tabular}

Source: ZEW

Table B-4: The effective tax burden with variation of currency conversion rate, disposable income $€ 100,000$, in $\%$

\begin{tabular}{lcccc}
\hline & France & Germany & UK & USA \\
\hline Single & & & & \\
PPP & 49.0 & 48.9 & 40.9 & 39.0 \\
Average nominal exchange rates & 49.0 & 48.9 & 40.8 & 38.5 \\
\hline S
\end{tabular}




\section{References}

Börsch-Supan, A. and A. Reil-Held (2001), How Much is Transfer and How Much is Insurance in a Pay-as-you-go System? The German Case, Scandinavian Journal of Economics 103, 505-524.

Brassat, M. and D. Kiesewetter (2003), Steuervorteile durch arbeitgeberfinanzierte Versorgungszusagen, Zeitschrift für Betriebswirtschaft 73, 1051-1076.

Devereux, M. P. and R. Griffith (1999), The Taxation of Discrete Investment Choices, IFS Working Paper 98/16 (Revision 2), London.

Devereux, M. P. and R. Griffith (2003), Evaluating Tax Policy for Location Decisions, International Tax and Public Finance 10, 107-126.

Elschner, C. and R. Schwager (2004a), The Effective Tax Burden on Highly Qualified Employees - An International Comparison, ZEW Economic Studies, Heidelberg, forthcoming.

Elschner, C. and R. Schwager (2004b), Do Employer-Provided Stock Options Lower the Compensation Costs?, ZEWnews English Edition 3, Stock Option Watch, III-IV.

European Commission (1992), Report of the Committee of Independent Experts on Company Taxation, Brussels.

European Commission (2002), Company Taxation in the Internal Market, Commission Staff Working Paper, COM (2001) 582 final, Luxembourg.

Fenge, R. and M. Werding (2002), Ageing and the Tax Implied in Public Pension Schemes: Simulations for Selected OECD Countries, CESifo Working Paper 841, München.

Gaube, T. and R. Schwager (2003): Consumption vs. Wage Taxation and the Capital Levy, Economics Letters 79, 15-19, 2003.

Gravelle, J. (1991): Income, Consumption, and Wage Taxation in a Life-cycle Model: Separating Efficiency from Redistribution, American Economic Review 81, 985-995.

Heady, C. (2003), The ,Taxing Wages 'Approach to Measuring the Tax Burden on Labour, CES-ifo working paper 967, München.

Jacobs, O.H. and C. Spengel (1996), European Tax Analyzer, Baden-Baden.

King, M.A. and D. Fullerton (1984), The Taxation of Income from Capital, Chicago.

Mendoza, G., A. Razin and L. Tesar (1994), Effective Tax Rates in Macroeconomics Cross-country Estimates of Tax Rates on Factor Incomes and Consumption, Journal of Monetary Economics 34, 297-323. 
Metcalf, G. (1996), The Role of Value-Added Tax in Fundamental Tax Reform, in: M. Boskin (ed.): Frontiers of Tax Reform, Stanford: Hoover Institution Press, 91-109.

OECD (2002), Taxing Wages 2001-2002, Paris.

Sutherland, H. (2001), Final Report Euromod: An Integrated European Benefit-tax Model, Euromod Working Paper No. EM9/01.

Winkelmann, R. (2002), Why Do Firms Recruit Internationally? - Results from the IZA International Employer Survey 2000, in: OECD, International Mobility of the Highly Skilled, Paris.

Winkelmann, R., A. Kunze, L. Locher, and M. Ward (2001), Die Nachfrage nach internationalen hochqualifizierten Beschäftigten - Ergebnisse des IZA International Employer Surveys 2000, IZA Research Report 4, Bonn. 